\title{
How can management scholars contribute with research in the COVID-19 crisis?
}

\section{Cite as}

American Psychological Association (APA)

Falaster, C., Martins, F. S., Storopoli, J. E., \& Ramos, H. R. (2020). How can management scholars contribute with research in the COVID-19 crisis? Editorial. Iberoamerican Journal of Strategic Management (IJSM), 19(2), 1-5. https://doi.org/10.5585/riae.v19i2.17875.

\section{INTRODUCTION}

As the Covid-19 crisis ensues throughout the world, researchers from several fields of research consider how they could contribute to the current understanding of the crisis. In the field of strategic management, we face a special problem as most companies scraped their strategic plans for the year 2020 as they are currently more focused on surviving the crisis with emergent strategies. Strategic management researchers are now in a position where their main object of research has been highly influenced by the pandemic and face the challenge of developing impactful and meaningful research in a world where all eyes are looking for answers to the crisis.

In the Iberoamerican Journal of Strategic Management, we decided that we would encourage researchers in our field to develop research that contributes to a better understanding of the pandemic crisis and their impacts on organizations. We are not currently announcing a special issue dedicated to the pandemic crisis. However, we are stating that we welcome and encourage research on the investigation of aspects that link the pandemic to organizations and strategy. 
We believe that it is crucial for researchers to acknowledge and to understand the impacts that the pandemic crisis has on organizations. The more we understand this crisis, the more we can contribute to reducing the effects it will have on organizations and jobs. Besides, we believe that this is a time when we, as researchers, have to contribute to society by helping in every way we can. The best way to contribute with our skills is to provide a better understanding of how, in which conditions, and to what extent the pandemic crisis will influence organizations.

We provide two following sections for this editorial. First, a suggestion of research themes to be addressed, and secondly, a section regarding the cautions we must have when researching the effects of the pandemic crisis.

\section{SUGGESTIONS OF RESEARCH THEMES}

Impacts of the pandemic crisis over firm performance. Some works are already looking into how the pandemic crisis will impact firm performance (Aifuwa et al., 2020; Gonzalez-Uribe \& Wang, 2020). This is a very important topic as the economic performance of the world will be hindered by the crisis. It is important not only to understand how the pandemic will reduce the performance of firms but also to investigate under which conditions this reduction will happen, in which industries, and depending on which firm-specific settings.

Strategic responses to the pandemic crisis. Which strategies have firms put up to deal with the crisis? Which kinds of strategic moves have been successful and reduced the impact of the crisis? How could these strategies shape businesses in the near future? It is especially interesting to investigate if firms can develop capabilities through the crisis and how these capabilities will shape future strategies.

Global value chains and the pandemic. As companies throughout the world will have to deal with the disruption of global value chains during the pandemic (Bonadio et al., 2020), it is important to investigate how this disruption could shape the future of global value chains. Will companies diversify their value chains to avoid future problems in similar situations? What have we learned with the challenges of finding alternatives and dealing with disruptions of the chain? 
Institutional pressures, adaptation, and conformity in times of pandemics. Institutions are crucial for strategic decisions and the following performance of firms. However, the institutional environment is usually perceived as the rules of the game that change in a very slow fashion (North, 1990). The challenges that the pandemic crisis imposed upon firms have greatly changed the way that business is conducted. But are institutional pressures reinforced or loosened during a crisis as the pandemic? Could the pandemic crisis spark an institutional change?

Pandemic-driven stress and its effects on decision-making. Organizations already struggle to maintain acceptable levels of strategic decision-making in normal circumstances, and in situations such as the current one, this becomes even more complex, subjective, and difficult. Decision-making is the cornerstone of most schools of thought in strategy, and crises escalate choices and consequences (Oroszi, 2018). Latin American organizations are sometimes considered more vulnerable in a plethora of dimensions, and the ongoing pandemic is most likely to influence decision-making in the area negatively.

Teams, coordination and multinational efforts. Crises stir trouble but also provide interesting aspects worth of studying for teams and coordination (Driskell et al., 2018). Whereas technologies may mitigate the negative effects of the pandemic on team coordination, new ways of organizing work and making group efforts and decisions may also come up.

Multiple stakeholders and conflicts in decision-making. Critical times impose extreme pressures not only on teams but also on stakeholders, especially external ones. Current literature still has gaps on conflicts between ideas as competing pressures and crises tend to overemphasize and distort stakes (van der Wal, 2020).

Born globals, startups, and innovation in times of crisis. What are the effects - both negative and positive - of crises on innovation? More specifically, what happens to supposedly more vulnerable beginning endeavors such as born globals (Pepelasis \& Protogerou, 2018) and startups (Haase \& Eberl, 2019)? What are the capabilities they have developed or are seeking in order to survive these troubling times?

SME Entrepreneurship and frugal innovation. As with born globals and startups, we must look to the opposite end of the scale. How are small and medium organizations dealing with the 
effects of the current crisis? Are there any behavior shifts and strategic alterations that can subside such negative consequences?

Countercyclical industries and fields during crises. In the Iberoamerican territories, are there any industries and fields that are gaining momentum in a countercyclical fashion? What are these and what features do they have to promote growth? Can this growth be sustainable once the crisis subsides? Agroindustrial and low-tech industries may be examples, but other fields can also shed light on the matter (Martins et al., 2019).

\section{CAUTIONS FOR RESEARCHING THE PANDEMIC CRISIS}

As the pandemic crisis is still undergoing as we write this editorial, we thought of providing some guidance about the special care researcher must-have when dealing with this delicate issue. These are ethical guidelines that we see as important to be followed to ensure a meaningful discussion in the academic field.

Do not put a value on lives and health. It is impossible to put a value on life. As researchers of the management field, we are focused on understanding the effects of the pandemic on organizations. We have seen statements treating the crisis as a tradeoff between lives and jobs, or between health and the economy. We are not in a position of pointing a side in this situation. We advise researchers always to remember that lives are invaluable.

Do not step outside of your field of research. Many scholars from several fields have conducted research trying to understand and predict the spread of the Covid-19 disease, mainly using their skills with data. This effort is remarkable; however, this is not a competence of the management field as we are not trained in understanding diseases. We, therefore, encourage researchers to look at the effects of the crisis in organizations, and we advise not to delve into understanding the disease per se as this is not our expertise.

Do not guide the research question by political agendas. We understand that there are many political interests regarding the results of research on the crisis. We also understand that it is tempting to answer direct questions posed by politicians in the issue. However, we advise scholars not to directly tackle into answering politically-driven questions and to maintain the impartiality we always have. 
Do not twist your theory/method/argumentation to fit a crisis. As of now, we see a surge on pandemic-related research on all fields. While in some fields this is expected (such as epidemiology or economics), not all management research is closely related to the topic. Several fields have also seen a surge in pandemic-framed research that is only marginally tangential to the topic - management included. Reshaping your study to fit the crisis it does not directly relate to is not only intellectually dishonest but also takes space and time from editors and reviewers from doing their job on papers that actually can contribute to the ongoing scenario.

\section{References}

Aifuwa, H. O., Saidu, M., \& Aifuwa, S. A. (2020). Coronavirus Pandemic Outbreak and Firms Performance in Nigeria. Management and Human Resources Research.

Bonadio, B., Huo, Z., Levchenko, A. A., \& Pandalai-Nayar, N. (2020). Global supply chains in the pandemic (No. w27224). National Bureau of Economic Research.

Driskell, T., Salas, E., \& Driskell, J. E. (2018). Teams in extreme environments: Alterations in team development and teamwork. Human Resource Management Review, 28(4), 434449.

Gonzalez-Uribe, J., \& Wang, S. (2020). The Effects of Small-Firm Loan Guarantees in the UK: Insights for the COVID-19 Pandemic Crisis. Available at SSRN 3382280.

Haase, A., \& Eberl, P. (2019). The Challenges of Routinizing for Building Resilient Startups. Journal of Small Business Management, 57(sup2), 579-597.

North, D. C. (1990). Institutions, institutional change, and economic performance. Cambridge University Press.

Oroszi, T. (2018). A preliminary analysis of high-stakes decision-making for crisis leadership. Journal of Business Continuity \& Emergency Planning, 11(4), 335-359.

Martins, F. S., Lucato, W. C., Vils, L., \& Serra, F. A. R. (2020). The effects of market and entrepreneurial orientation on the ambidexterity of multinational companies' subsidiaries. European Business Review, 32(1), 4-25.

Pepelasis, I. S., \& Protogerou, A. (2018). A break with the past? The shift from inwardlooking to internationally competitive and born global firms in Greece during the crisis. Managerial and Decision Economics, 39(8), 879-887.

van der Wal, Z. (2020), Being a Public Manager in Times of Crisis The Art of Managing Stakeholders, Political Masters, and Collaborative Networks. Public Administration Review. Accepted Author Manuscript. doi:10.1111/puar.13245. 